\title{
Mitogen-Activated Protein Kinase 13
}

National Cancer Institute

\section{Source}

National Cancer Institute. Mitogen-Activated Protein Kinase 13. NCI Thesaurus. Code C26368.

Mitogen-activated protein kinase 13 (365 aa, $\sim 42 \mathrm{kDa}$ ) is encoded by the human MAPK13 gene. This protein plays a role in both mitogenic signaling and serine/threonine phosphorylation. 